\title{
AN ANALYSIS OF THE CONTENT OF WAHDAT AL-WUJŪD The Relationship between Essence and Existence
}

\author{
Abdullah Kartal \\ Uludağ University, Bursa-Turkey
}

\begin{abstract}
Discussions about "the unity of existence" (wahdat al-wujūd), which is always considered together with the name of Ibn 'Arabī, are common not only in Sufism but also in almost all domains of Islamic thought. In this respect, the problem of the unity of existence is a notable and much-debated issue in the history of Islamic philosophy, which results in countless comments on and approaches to the matter. Nevertheless, no solid conclusion or solution is attained. This is primarily because of the lack of a precise explanation of the nature and content of the unity of existence manifested by Ibn 'Arabì and his followers. The unity of existence seems to have two basic principles that can be formulated as follows: "Existence as such is God, and immutable entities (al-a yyan al-thābita), the truth of contingencies, are not created and existence is subsequently attached to truth." These two elements exclusively determine whether a doctrine is the unity of existence, whereas the principles abovementioned are entirely grounded on discussions about the relationship between essence and existence. The first and second principles are conclusions of the following opinions, respectively: "The existence of Allah is identical with His essence" and "among contingent beings, the existence is subsequently added to the essence." In this context, this study therefore seeks an evaluation not only of what unity of existence is but also of the importance of the relationship between essence and existence in
\end{abstract}


terms of the unity of existence as a notable discussion point in Islamic thought.

Key Words: Unity of existence (waḩdat al-wujūd), essence, existence, Ibn 'Arabī

\section{Introduction}

Essence and existence are among most essential and important universal concepts of philosophy, kalām and Sufism within Islamic thought. As Izutsu duly notes, the relationship between these two concepts is one of the most original philosophical theses in Islamic thought. ${ }^{1}$ Obviously, discussions about the relationship between essence and existence result from efforts to explain the relationship between Allah and creation, which constitute the essence of Islamic revelation, on a metaphysical basis. In other words, when it is necessary, as a metaphysical problem or issue, to explain the relationship between Allah and the universe, subject to the question of faith, the disciplines are used to reveal possible problems regarding the relationship between Allah and the universe (creation) by means of solutions generated on the axis of the relationship between essence and existence - the various theses on the matter will be treated below. In this respect, arguments and solutions concerning essence and existence provide us with notable clues about the studied disciplines' points of departure and preferences. Nevertheless, it is possible to assert that the discussions conducted and theses generated related to essence and existence are the basis on which the entire structure of Islamic thought is founded. ${ }^{2}$

In the history of Islamic thought, theologians and great philosophers such as al-Fārābī (d. 339/950) were the first to discuss the rela-

1 Toshihiko Izutsu, The Concept and Reality of Existence (Kuala Lumpur: Islamic Book Trust, 2007), 133.

2 For instance, Henry Corbin assesses the views of al-Fārābī on the relationship between essence and existence as a milestone in the history of metaphysics, whereas Hüseyin Atay claims that the starting point of Ibn Sinnā's philosophy is his distinction between essence and existence. See Henry Corbin, History of Islamic Philosophy (translated into English by Liadain Sherrard with Philip Sherrard; London \& New York: Kegan Paul International \& The Institute of Ismaili Studies, 1993), 160; Hüseyin Atay, İbn Sina'da Varlı Nazariyesi (Ankara: Gelişim Matbaas1, 1983), 78. 
tionship between essence and existence; however, it was the great thinker Ibn Sinā (d. 427/1037) who provided the issue with various new aspects and brought the studies to their peak. ${ }^{3}$ Indeed, the following discussions remain mostly within the boundaries prescribed by Ibn Sīnā. For Ibn Sīnā, because the Necessary Being needs no cause to exist - given that its definition excludes the need for cause ${ }^{4}-$ it is impossible to discuss any priority or separation between His essence and existence. In this context, existence is neither an attribute nor an accident of essence for the Necessary Being. In other words, godhood as essence is not a prior essence, to which existence is subsequently added as an attribute. On the contrary, because His essence is His existence, no subsequence is related to Him, unlike contingent beings. ${ }^{5}$ According to Ibn Sīnā, contingent beings require a cause to exist; as a result, their existence comes from another. ${ }^{6}$ In this sense, Ibn Sinā dismisses the distinction of essence-existence in the Necessary Being and claims that the essence is prior to the existence, which is added to the former afterwards, in contingent beings. This is because in the essence of all things, the conception of whose self does not include its existence - namely, the contingent beings - the existence is not the constituent of essence. Therefore, existence is not a necessary element within the essence of contingent beings; existence is but a possibility for such beings. ${ }^{7}$ As a result, for Ibn Sinnā, the exist-

For further information, see Izutsu, ibid., 108-132.

According to Ibn Sīnā, Necessary Being is necessary in His self and therefore needs no cause: "Necessary Being has no cause; this is evident. If He had a cause, He would have obtained His existence from such cause." Abū 'Alī Husayn ibn 'Abd Allāh ibn 'Alī Ibn Sīnā, Kitâbu'ş-Şifâ: Metafizik [= Kitāb al-Shifāa': alIläbiyyāt] (translated into Turkish, with the original text, by Ekrem Demirli and Ömer Türker; Istanbul: Litera Yayınc1lık, 2005), I, 36. Also see Ibn Sīnā, Issaretler ve Tembibler [= al-Ishärāt wa-l-tanbīhät] (translated into Turkish, with the original text, by Ali Durusoy, Muhittin Macit, and Ekrem Demirli; Istanbul: Litera Yayınc1lik, 2005), 124-132.

5 Ibn Sīnā, İsaretler ve Tembibler, 129-131.

6 Ibn Sīnā says: "Anything whose truth in itself is a possibility cannot exist by means of its own self. Its existence, which originates from itself, is prior to its absence due to contingency. Therefore, if one among two is prior, this is because the former is either ready or lost. Therefore, the existence of anything, whose existence is contingent, comes from another." Issaretler ve Tembibler, 127.

7 Ibn Sinnā says: "In essence of something, nothing can be common together with necessary being. This is because the essence of every single thing other than it is that the possibility of being is required for itself. As for being, it is neither essence 
ence is something more than essence in contingent beings; it is an element added to essence. ${ }^{8}$

Pursuant to views of Ibn Sinnā, despite certain discipline-based variations, the debates on the relationship between essence and existence concentrate on the ontological primacy of essence and existence with respect to one another and as to whether existence is identical with essence or whether it is an added attribute of essence. The principal questions on the issue are as follows: Is essence primary and existence $(w u j \bar{u} d)$ accidental, or vice versa? Is the existence of Allah prior or subsequent to His essence?

Responses to such questions are generally collected in three groups:

1. Theologians such as Abū 1-Hasan al-Ash`arī (d. 324/935-936) and Mu'tazilī Abū l-Husayn al-Bașrī (d. 436/1044) argue that in both necessary and contingent beings, existence is identical with self and essence, because it is not an attribute.

2. As is seen above, Ibn Sinā and certain philosophers assert that no distinction between essence and existence is in question for necessary being, while for contingent beings, existence is distinct from essence and added to it afterwards.

3. According to theologians who follow al-Rāzì (d. 606/1210), existence is an attribute distinct from and added to essence in both necessary and contingent beings.

of something nor a part of the essence of something. I mean, existence is not included in grasping things with essence. Rather, existence has come upon essence." Ibid., 131.

8 About the views of Ibn Sinnā on the relationship between essence and existence, see Atay, ibid., 65-94; id., "Mâhiyet-Varlık Ayırımı," in Müjgan Cunbur and Orhan Doğan (eds.), Uluslararası İbn Sina Sempozyumu (Bildiriler) (Ankara: Başbakanlık Basımevi, 1984), 139-166; Mahmut Kaya, "Mâhiyet ve Varlık Konusunda İbn Rüşd'ün İbn Sînâ'yı Eleştirmesi,” in Aydın Sayılı (ed.), İbn Sînâ: Doğumunun Bininci Yılı Armağanı (Ankara: Türk Tarih Kurumu Basımevi, 1984), 453-459.

9 See Abū 'Abd Allāh Fakhr al-Dīn Muhạmmad ibn 'Umar al-Rāzī, al-Mațālib al'āliya min al-'ilm al-ilāhō (ed. Aḥmad Hijāzī al-Saqqā; Beirut: Dār al-Kitāb al'Arabī, 1987), I, 209-213; Abū l-Barakāt Nūr al-Dīn 'Abd al-Raḥmān ibn Aḥmad ibn Muhammad Jāmī, al-Durra al-fākhira fì tahqqīq madhābib al-ṣūfiyya wa-lmutakallimìn wa-l-hukamā al-mutaqaddimìn (eds. Nicolas Heer and 'Alì 
Sufism is subject to reflections of problems and debates in Islamic thought, as well as similar considerations. Apart from Ibn 'Arabī (d. 638/1240), the greatest figure in Sufism, there are Sufis such as alQūnawī (d. 673/1274) and al-Qayșarī (751/1350) who address the relationship between essence and existence under different titles. ${ }^{10}$ Although some Sufis do not directly study the matter, they are not entirely indifferent to the question. For instance, studies by Ibn 'Arabi on various issues are necessarily related with essence and existence. Why is the relationship between essence and existence important in terms of Sufism? Or which objectives did Ibn 'Arabī and his followers pursue in discussions about this issue, and which conclusions did they draw? We think that the issue of the relationship between essence and existence in Ibn 'Arabì School is directly connected with the unity of existence. The doctrine of the unity of existence wants to explain the relation Allah, universe and man pursuant to observation method and is necessarily based on the relationship between essence and existence. In past and present studies, the unity of existence is the most important and remarkable issue of Sufism. Studies of this concept lay stress on two points: First, such studies stress when and by whom was the term "unity of existence" used - a question outside the scope of this study. ${ }^{11}$ Second, such studies analyze the meaning, content, and basis of the term. This article aims to address the concept of the unity of existence in this respect. Analysis of the content and basis of the notion of the unity of existence leads us directly to an analysis regarding the relationship between essence and existence. This is because we believe that the principal propositions of the unity of existence are derived from the relationship between essence and existence. There are several reasons for this conviction. First, al-

Mūsawī Bahbahānī; Tehran: McGill University Institute of Islamic Studies \& Dānishgāh-i Tehran, 1980), 2.

10 Al-Qūnawī treats this problem in his correspondences with Nașīr al-Dīn al-Ṭūsī. See Ṣadr al-Dīn Muḥammad ibn Isḥāq ibn Muḥammad al-Qūnawī, Sadreddin Konevî ile Nasireddin Tûsî Arasında Yazışmalar: al-Murāsalāt (translated into Turkish by Ekrem Demirli; Istanbul: İz Yayıncılık, 2002), 53-63. Al-Qayșarī analyzes the issue in the preface to his commentary on Fușūs al-bikam. See Sharaf al-Dīn Dāwūd ibn Mạ̣mūd ibn Muhammad al-Qayṣarī, Sharḅ Fuṣūṣ al-ḅikam (ed. Jalāl al-Dīn Āshtiyānī; Tehran: Sharikat-i Intishārāt-i 'Tlmī va-Farhangī, 1383 HS), $13-42$.

11 For discussions of the problem, see Su'ād al-Hakīm, al-Mu 'jam al-șūfi: al-Hikma fì ḥudūd al-kalima (Beirut: Dandara li-1-Ṭibā'a wa-l-Nashr, 1981), 1145-1157. 
Kāshānī (d. 730/1329), a notable commentator of Ibn 'Arabī and perhaps the first thinker to define the unity of existence as a concept, grounds his definition of the unity of existence entirely on the connection between existence and essence. Al-Kāshānī defines the unity of existence as follows:

Unity of existence means that the existence is not divided as the necessary and the contingent. According to this group, existence is not what philosophers and theologians understand about it because most of them consider it as accident. The existence, which they deem accident, is what realizes the truth of every present and if so, it cannot be anything other than Haqq. The self, defined through the attribute of unity, has two values: Firstly, the truths contained and engirdled by the self are the same; they are not other than the self. In turn, existence is one of these truths and the most obvious and apparent faculty of intellect. Thus, in this sense, existence becomes identical with the self. ${ }^{12}$

This definition by al-Kāshānī serves as an appropriate point of departure for us. He principally insists that existence is not accident or specific being. Rather, as al-Nābulusī (1143/1731) notes, existence here is not existence as accident ascribed to a substance nor is it either specific existence used for Allah. Al-Kāshānī indicates that Sufis do not attribute being to a distinction between essence and existence, and notes to the necessity of treating the unity of existence as "existence in itself." At exactly this stage, the relationship between essence and existence appears as problematic. Therefore, the relationship between essence and existence determines what unity of existence is or is not. According to Sufis, existence is not an attribute added to essence or self but instead is identical with the self. Therefore, the main principle of the unity of existence is the following phrase: "Existence as such is Haqq (al-wujüd min hayth" huwa huwa l-Haqq)."13 In other words, in consideration of the relationship between essence and existence, what lies at the heart of the unity of existence is that existence is not an attribute but is identical with the self.

12 Kamāl al-Dīn 'Abd al-Razzāq ibn Ahmad al-Kāshānī (as al-Qāshānī), Laṭā'if ala lām fì ishārāt abl al-ilhām (eds. Aḥmad 'Abd al-Rahịm al-Sāyiḥ, Tawfīq 'Alī Wahba, and 'Āmir al-Najjār; Cairo: Maktabat al-Thaqāfa al-Dīniyya, 2005), 710.

13 Al-Qayṣarī defines it without mentioning the predicate as "existence as such (alwujūd min ḥaythu huwa huwa)." See al-Qayșarī, Sharḥ Fușūṣ al-ḥikam, 13. 
In light of al-Kāshānī's definition, we believe that there are two principal, interconnected and distinctive propositions related to the unity of existence. First, "existence as such is Haqq," the "truth of contingent beings is not created, existence is added to them afterwards (question of al-a yyān al-thābita)." The first proposition about the unity of existence refers to the relationship between essence and existence in necessary being, whereas the second is about the same relationship in contingent beings. Thereupon, the unity of existence cannot be conceived without analyzing the relationship between essence and existence. Throughout the history of Sufism, Sufis' point of departure from various discourses has been the criticisms of two previously mentioned propositions regarding the unity of existence; as they developed systems related to these views, the opposite approaches have also focused on essence and existence. Consequently, we believe that the response to what unity of existence is should be searched within the framework of the relationship between essence and existence. In this study, we preferred to address the relationship between essence and existence separately in necessary being and contingent beings. Therefore, this article will treat these two issues and their relationship with the unity of existence.

\section{A. Identity of Essence and Existence in Necessary Being: Existence as such is Haqq}

Being has been a principal concept since the beginnings of Sufism. Indeed, the first Sufis used wujū as a term that indicates the conditions that confronted them during their course in the order. In this sense, wajd (ecstasy), wujūd (existence), and tawājud (willful rapture) - which is to force oneself to wajd-were developed under the influence of primary Sufi discussions of human acts and brought into the future. These words merged under the meaning "to find" or "to know," and over time, they gained new interpretation in connection with wujü $d$ and mawjüd, which mean "existence" and "existing." In this respect, Sufi literature may provide Islamic thought with useful contributions with respect to the settlement of words regarding existence and being. The sense "to find," first ascribed by Sufis to the

14 For the use of this principle, see al-Qayșarī, ibid., 13-14. This phrase is occasionally formulated as "there is one existence, that of Haqq." See 'Abd al-Ghani ibn Ismā̄īl al-Nābulusī, Gerçek Varlık: Vabdet-i Vücûd'un Müdafaası [= al-Wujūd al-ḥaqq wa-l-khitāa al-șidd (translated into Turkish by Ekrem Demirli; Istanbul: İz Yayınc1lik, 2003), 20. 
words, has been an explanation of the relationship considered by Sufis to exist between being and existing. ${ }^{15}$ In this context, existence gained a meaning related to "to know" and "to be known" for Sufis in almost every era. The term ablal-kashf wa-l-wujüd (masters of manifestation and existence), used by Sufis to define themselves, became synonymous with one who both possesses wajd and is abl al-wujūd, that is, is able to obtain the Truth, al-Haqq. Following Ibn 'Arabī and al-Qūnawī, theoreticians of new Sufism maintained the relationship between existence and knowledge/knowing.

Following Ibn 'Arabī, the Sufi conception of existence took form as an extensive interpretation of the God-universe with God at the center. On the one hand, this approach involves grounding the universe on God through causality, which enables us to obtain knowledge about God, and explaining the problem of creation in this respect - it is formulated as the relationship between knowing the universe in broad sense and knowing both the self and God in the narrow sense. On the other hand, the question concentrates on finding an explanation of how and in what context the relationship of God to both the universe and man continues. In other words, the attempt was primarily intended to explain how and why the universe exists, and accordingly, to determine how the relationship between God and the universe is realized. This contemplation depends on the proposition "Existence as such is Haqq." This point is the primary proposition of Sufi metaphysics. That the expression eventually became Sufi literature's motto is notable because the existence of this fact shows its importance in Sufism. The phrase is occasionally formulated as, "There is one existence, that of Haqq ${ }^{16}$ or "Wujūd as such is Haqq." Certain points require understanding to permit a conception of the Sufi approach to the matter. First, the meaning of concept of existence requires clarification. In fact, this may be as a continuation of the difficulties caused by the word "existence" in metaphysics generally. Attempting to explain the meaning of existence, Sufis note that existence is outside all categories. For instance, Dāwūd alQayșarī indicates that in the Sufi explanation of "existence as such,"

15 About the use of this concept by early Sufis, see Abū l-Qāsim Zayn al-Islām 'Abd al-Karīm ibn Hawāzin al-Qushayrī, al-Risāla al-Qushayriyya (eds. Marrūf Mușțafā Zurayq and 'Alī 'Abd al-Ḥamīd Balțajī; Beirut: Dār al-Khayr, 1991), 61-64.

16 Al-Qūnawī, Tasavvuf Metafiziği: Miftāh ghayb al-jam` wa-l-wujūd (translated into Turkish by Ekrem Demirli; Istanbul: İz Yayınc1lık, 2002), 21, 23; al-Qayṣarī, Sharḅ Fușūṣ al-ḅikam, 13; al-Nābulusī, Gerçek Varlı, 20, 26. 
existence is outside any qualification such as universal, particular, one or many. According to al-Qayșarī, existence in "existence as such" is neither substance, nor accident, nor even existence outside or within the mind. ${ }^{17}$ Later Sufis distinguish existence in this sense from existence as "to be present;" accordingly, the mind searches for the meaning of "to be present" in natural and general terms, whereas existence is a kind of being present. As a result, Sufis treated the problems arising from these meanings. Therefore, to understand the Sufi view of existence, we first should examine the difference between existence and existing as a reality to which the mind naturally steers and existence as a term that expresses God.

Another point to understand about existence is that it is not a concept that has any antonyms whatsoever. This is the main reason that existence cannot be known. Existence is not the antonym of nothingness and in fact, there is no such thing as nothingness. ${ }^{18}$ Nothingness is only a potentiality that makes Being possible to emerge and appear.

In terms of the Necessary Being, the principal question about being is the relationship between existence and essence. The Sufi attitude about this problem is as follows: Sufis discuss the personality, attributes, and names of Allah in detail. These are issues with a certain turn of phrase and proper terminology. For example, Sufis ceaselessly address theological and philosophical issues such as the relationship between the self and its attributes, the problem of the primacy of attributes, the names of Allah, and how and by whom these names will be determined. Moreover, Sufis insist that the source of our knowledge about Allah is divine names. Through the use of such concepts, Sufis attempt to explain how to envisage Allah and participate in discussion around those concepts. Nevertheless, a new approach comes to light, especially from Ibn 'Arabī and al-Qūnawī: to attempt to address the God conception formed within the line of relationships between self and attributes, as Absolute Being and His

17 Al-Qayșarī expresses the problem as follows: "It should be noted that existence as such ( min bayth ${ }^{u}$ buwa) is different from exterior and intellectual existence, since each of the latter is its kinds. Existence as such, namely, unconditional existence, is not restricted with absoluteness and constraint. Existence is neither universal nor particular, neither general nor private, neither one with a unity added to itself nor plural." Al-Qayșarī, ibid.,13.

18 About the mentioned aspect of wujūd, see al-Qayșarī, ibid., 13-22. 
emergence and manifestations. The relationship between the essence and existence of God is considered a part of the question regarding the relationship between His self and qualities. Thereupon, another problem comes to the fore: Having the problems and terminology descending from kalām tradition, Sufis began to confront a rich conceptual world through philosophical heritage. Along with some other factors, this fact paved the way for a rich terminology; consequently, the interpenetration among concepts and topics from various sources became one of the primary difficulties involved in understanding Sufi texts.

With respect to Allah, it is possible to discuss an essence and an existence. Essence is expressed by the terms such as the self of Haqq, His truth, origin, or identity. Allah also has an existence. Accordingly, what is the relationship between His existence/essence and truth? In other words, is existence identical with His self, or is it an attribute attached to self? This is clearly the primary concern of the Ibn 'Arabī School. Al-Qūnawi moves from two points of view in analyzing this problem. First, he seeks an explanation that does not injure the simplicity and unity of Self; second, he attempts to avoid the delusion that He is dependent or in need of anything whatsoever. Therefore, in addressing the essence and existence of God and their interconnection, one must demonstrate the simplicity and unity of Allah on the one hand, and to determine that He is the self-sufficient existence that needs nothing, on the other hand. ${ }^{19}$ In other words, the solution to the problem is based on the analysis of the concept of necessary being.

Next, through the perspective of the commentators of Ibn 'Arabī, the first thing to understand with respect to the being of Allah is that existence is not an addition to His essence. This is because if wujüd is considered an addition to the essence of God, then God incorporates both an existence and an essence. In that case, God is a being who is a compound of essence and wujüd. However, our most explicit verdict about God is that He is both simple and one. Because God cannot be considered composite in any sense, existence cannot be ascribed to His truth. Once we accept that existence of God is added to His truth, we would be asked from whence such existence was gained. His existence would be either autogenous or dependent on something else. If His existence were via itself, then a second primacy

19 Al-Qūnawī, Yazışmalar, 185. 
should have been present. However, this is impossible, because God is one. Alternatively, existence is gained from something else or is created by God, whereupon the existence of God should either be grounded on something else or be related to a changing thing. Nevertheless, both are impossible for God, because they contradict the idea of a "necessary being." Another aspect of the problem concentrates on the question of unity and multitude. If existence and truth are considered separate, then God should have a truth and an existence. However, God is one and simple in an absolute sense. Therefore, in God, existence or truth is one and identical. Accordingly, if God is existence with no essence other than His existence, namely, if His existence is the same as His self, then our knowledge about His existence - and the knowledge of the human mind about God consists of knowing him as sheer existence - means to know God entirely. However, we know that our knowledge about God is limited. It is impossible for us to know one aspect of His being and not another, because His being is one and simple. If He is known on one side and unknown on the other, then His being is a composite concept. This would also contradict the idea of the Necessary Being. This problem is solved by interpreting Absolute Being as a negative, not positive expression or definition. Absolute Being or One is merely an existence to make an expression and indication possible. In this respect, being or One is not a positive qualification, it is a negative one. As alQunawi states, the negative does not express knowledge. ${ }^{20}$ The Sufi distinction in this respect is often overlooked. Al-Nābulusī says: "When we call Haqq as wujüd, we mean an expression that approximates Him to human mind." 21 The essence and self of God is one and the same. However, wujüd, in the sense of the self and the essence of God, is an ambiguous and negative qualification. Otherwise, to know His existence would be synonymous with knowing His self, which is impossible. Therefore, according to Sufis, for God, existence is not an attribute ascribed to self - it is identical with the self. Pursuant to the definition of the unity of existence by al-Kāshānī, "unity of existence means indivisibility of existence as necessary and contingent. Thereupon, existence is not an accident, but it is what realizes

\footnotetext{
20 For assessments by al-Qūnawī on the issue, see Yazışmalar, 53-58.

21 Al-Nābulusī, Gerçek Varlık, 20.
} 
the truth of every present thing and such a thing can be nothing but Haqq. In this respect, existence has become identical with self." 22

Why do the commentators of Ibn 'Arabī such as al-Qūnawī, alQayșarī and al-Nābulusī always ground on the relationship between existence and essence in analyzing the unity of existence? In other words, with respect to Allah, why do those interpreters consider existence identical with essence (self) and not as its attribute?

We believe that the principle of identity of essence (self) and existence was obligatory to justify the unity of existence, because the proposition "existence as such is Haqq" necessitates considering existence as the primary element in the doctrine of the unity of existence. Otherwise, if existence was an attribute ascribed to essence (self), we would have overlooked the fact that His existence is both simple and single (one). However, simplicity and absolute unity invalidate the compound character that there is an essence and an existence separate from one another. Therefore, to discuss the unity of existence means to discuss the unity of something that corresponds to Haqq, in other words, the absolute unity that is necessarily present in the phrase "existence as such is Haqq." Accordingly, the identity of essence and existence in God is the primary principle of the unity of existence, which means that being cannot be divided as necessary and contingent. Through the means of "existence as such is Haqq," the advocates of the unity of existence have justified that God is an absolute being within the scope of the relationship and duality between God and the universe and that such is the existence of Haqq.

Historically, the course of discussion among Sufis regarding the unity of existence clearly shows that the main principle of the unity of existence is the identity of essence and existence. Indeed, Sufis, who object to the unity of existence, primarily concentrate their criticisms on the problem of the identity between essence and existence. For instance, it is notable that 'Alā' al-Dawla al-Simnānī (d. 736/1336), one of the first Sufis to criticize Ibn 'Arabī and the unity of existence, grounds his criticism on the definition of Allah as "absolute being" by Ibn 'Arabi ${ }^{23}$ The assessment by al-Simnānī is apparently directed to the basic proposition that "existence as such is Haqq," which consti-

\footnotetext{
22 Al-Kāshānī, al-Risāla, 710.

23 'Abd al-Raḥmān Jāmī, Nefahâtü'l-üns [= Nafahāàt al-uns min ḥaḍarāt al-quds] (eds. Süleyman Uludağ and Mustafa Kara; Istanbul: Marifet Yayınları, 1995), 658.
} 
tutes the basis of the unity of existence. al-Imām al-Rabbānī (d. 1034/1624), a follower of al-Simnānī, also concentrates his criticism of the unity of existence on the principle of the identity between essence and existence. Indeed, in one of his letters, al-Rabbānī indicates that he observes that the truth of Haqq cannot even be called as existence once one has attained the ultimate point of Sufi experience. ${ }^{24}$ For al-Rabbānī, whereas existence logically requires nothingness as its antonym, the truth of self is excluded from concepts in need of antonyms. According to him, "how can an existence, which can be replaced by its antonym, attain the rank of self? If we call this rank as existence, it is due to the shortage of expression. Such nomination refers the existence which nothingness cannot attain." ${ }^{25}$ Therefore, the self, which is beyond our knowledge and intelligence, is even excluded from existence as an attribute. With respect to whether existence is an attribute or whether existence is added to essence, alImām al-Rabbānī seems to be in the camp claiming that existence is an attribute of the self and thus adds to it. Such an approach is an explicit criticism of the first proposition of the unity of existence, namely, "existence as such is Haqq."

At this point, the discussion of the relationship between the unity of existence and the identity of essence and existence between 'Abd al-Karīm al-Jīlī (d. 826/1423), a disciple of Ibn 'Arabì School, and 'Abd Allāh al-Būsnawī (d. 1054/1644), a strict defender of Ibn 'Arabī, is very interesting and provides a better understanding of the matter. As seen above, the basis of the unity of existence is that existence is not an attribute of, but is identical with, the self. Indeed, Ibn 'Arabi and later his commentators believe that with respect to the ranks of existence, the self cannot be defined through any name, attribute, qualification, or connection and that the first rank, namely, abadiyya, is the rank of absolute being, which means that existence is not an attribute, because when we refer to the self as existence, we provide no information about the self. In the words of al-Qayșari, "If existence were accident, it would have existed with a subject matter that exist-

24 Abū l-Barakāt al-Imām al-Rabbānī Aḥmad ibn 'Abd al-Aḥad ibn Zayn al-cābidīn al-Sirhindī, Mektî̉bât [al-Maktūbāt] (translated into Turkish by Abdulkadir Akçiçek; Istanbul: Fatih Kitabevi, n.d.), I, 244-245.

25 Al-Imām al-Rabbānī, ibid., I, 244. 
ed before it. Then, a thing should have existed prior to its self... This is why it is impossible that existence is added to its self." ${ }^{26}$

Here, al-jîli develops an interpretation that contradicts the abovementioned fundamental connection, although he does not directly criticize Ibn 'Arabī and his commentators. According to al-Jīlin, "existence is an attribute of the self." 27 Thus, al-jili defines the first rank, indicated as absolute being and abadiyya by the commentators of Ibn 'Arabī, as "nothingness which precedes existence." This means that at this rank the self, which is exempt from all connections, does not even possess a connection to existence. The second degree, however, can only be referred to as an absolute being and abadiyya: "The second rank is inferior to the first, because at this stage, the existence becomes visible in the self. Whereas at the first rank, the self is exempt from connection with existence." ${ }^{28}$ According to al-Jīlì, in the first rank, in the event that the self is excluded from any name, attribute, or connection, we cannot ascribe any predicate or decree to it. Accordingly, the self, which has not become visible in any manner, is far from becoming the object of any type of knowledge. In such a case, existence (which joins the self afterwards, namely, at the second rank (called by al-jîlī as lähiq: one who attains ${ }^{29}$ ), also includes a judgment because we now refer to the existence of the self, a trait that was not present during the first stage.

Therefore, unlike Ibn 'Arabī and his commentators who defend the identity between existence and self during the first phase, al-jili starts from the fact that existence is an attribute and only later considers existence as attached to the self. For us, this nuance shows how al-Jîli differs from Ibn 'Arabī school in the context of the most fundamental principle related to the unity of existence. Accordingly, in Ibn 'Arabi tradition, the doctrine is primarily grounded on existence, whereas according to al-jīin, the system is primarily based on the self, rather than existence. The interesting point is how and in which context the views of al-jilin, who believes that existence is added to es-

\footnotetext{
26 Al-Qayṣarī, Sharḥ Fușūṣ al-ḥikam, 13.

27 Quṭb al-Dīn 'Abd al-Karīm ibn Ibrāhīm ibn 'Abd al-Karīm al-Jìlī, al-Kamālāt alilābiyya fì l-ṣifāt al-Muḥammadiyya (ed. Sa`īd 'Abd al-Fattāḥ; Cairo: Maktabat 'Ālam al-Fikr, 1997), 71.

28 Al-Jīìi, Marātib al-wujūd wa-haquīqat kull mawjūd (Cairo: Maktabat al-Qāhira, 1999), 17; id., al-Kamālāt al-ilābiyya, 56.

29 Al-Jīlī, al-Kamālāt al-ilābiyya, 56.
} 
sence, are addressed by the commentators of Ibn 'Arabī. Indeed 'Abd Allāh al-Būsnawī, a serious defender of Ibn 'Arabī, severely criticizes al-Jìli for his abovementioned approach, pursuant to the claim that the identity between essence and existence is the fundamental principle of the unity of existence. Quoting al-Qūnawī, al-Būsnawī states the two fundamental propositions of the tradition, namely, existence is identical with the self at the first stage and for those other than the self, existence is added to essence. Next, al-Būsnawi analyzes the views of al-Jīlī. The basis for al-Būsnawì's criticisms of al-Jìlì is that if we are to assert that existence is a connection and becomes visible in self at the second stage, then we will have to accept that the self does not exist at the first stage when it lacks the quality of wujüd and that the existence infiltrates the self at the second stage. This means that whereas al-Jili argues that the self is exempt from a connection with existence, al-Būsnawī ascribes the connection of "nothingness" to the self. Al-jili's mistake is to rely on the judgment that existence is an attribute and to refrain from calling the self an "absolute being." For al-Būsnawī, al-Jîli is right in not ascribing any attribute to the self. However, wujüd is not an attribute that we can ascribe to the self. In the words of al-Būsnawī, we cannot say that "a thing belongs to itself. Because, that thing is itself;" therefore, because existence is already identical with the self, we do not ascribe it to the self. ${ }^{30}$ Indeed, alBūsnawi criticizes al-Jìli for defending the addition of existence to the self and considers the attachment of existence to the self as a deviation from the unity of existence. This means that (at the very least), alBūsnawī's opposition to Sufi tradition is confirmed by a defender of Ibn 'Arabī.

Consequently, the view of the Ibn 'Arabi School about the relationship between essence and existence - in logical terms, the proposition "there is self," - is (pursuant to Kantian classification) an analytical proposition. Although "there is" is a predicate in terms of grammar and logic, it is actually different from the predicate in, for example, the proposition "man is mortal." In the latter example, the predicate adds something that was not already present in the subject, whereas "there is self" adds nothing to the subject. Existence is already within the scope of the concept of self. That the existence is not

For al-Būsnawī's views, see 'Abd Allāh 'Abdī ibn Muhammad 'Abd Allāh alBūsnawī, Kitāb al-qirār al-rūḥ̄ al-mamdūd li-l-adyāf al-wāridīn min marātib al-wujūd (MS Istanbul: Süleymaniye Library, Cârullah Efendi, no. 2129), 1a-27b. 
an addition to or an attribute of essence, on the contrary, that it is the same as essence, entails the proposition "existence as such is Haqq," which means that existence is both single and indivisible.

\section{B. The Status of Existence as Attachment to Essence in Contingent Beings: al-A yyän al-tbäbita or the Nonactual- ization and Nonexistence of Contingent Truths}

In terms of Haqq, Sufis derived from the identity of essence and existence the primary proposition of the unity of existence, namely, "existence as such is Haqq;" thus, they not only indicated that existence is the primary element but also proved that there is a single existence in an absolute sense. However, if the universe also exists within the scope of the relationship between Allah and the universe, and if this existence entails plurality, how can we explain such plurality and how can we talk about absolute unity in spite of that plurality? This is one of the main problems faced by Sufis who defend the unity of existence. This problem impels us to analyze and search for a solution to the relationship between essence and existence in contingent beings. Sufi thought (which defends the unity of existence) considering the relationship between essence and existence in contingent beings can be summarized in the following words of al-Qūnawī: "For Haqq, existence is same with the essence. As for those other than Haqq, existence is an addition to the truth. ${ }^{" 1}$ Pursuant to his definition, in contingent beings, essence and existence are separate, existence is added to essence and existence is obtained from some other thing. The concept of contingency means "something whose existence and absence is identical;" therefore, contingent beings need something else in order to exist. Indeed, the meaning of the concept is most clearly expressed in the opening phrase of al-Futūhat alMakkiyya by Ibn 'Arabĩ: "Thank God who brings things into being from nothing and absence of nothing." 32

With respect to contingent beings, essence is used as synonymous with truth. Nevertheless, Sufis use "identical ('ayn)" for the single essence or existence and "truths ( $\left.a^{c} y \bar{a} n\right)$ " for all contingent beings.

Al-Qūnawī, Tasavvuf Metafiziği, 23.

32 Abū 'Abd Allāh Muhyī al-Dīn Muhammad ibn 'Alī Ibn 'Arabī, al-Futūhāt alMakkiyya (ed. 'Uthmān Yahyyā; $2^{\text {nd }}$ edn., Cairo: al-Hay’a al-Mișriyya al-'Āmma li-lKitāb, 1985), I, 41. 
Ibn 'Arabī adds an attribute to this concept and attains al-a yyān althäbita (immutable entities). For al-Qūnawī, the immutable entities in the Sufi concept of immutable entities correspond to "certain absence" and "invariable thing" in Mu'tazili terminology. ${ }^{33}$ In this respect, immutable entities signify the truth and essence of contingent beings; research on the relationship between essence and existence in contingent beings requires an analysis of immutable entities.

In Sufi literature, immutable entities include meanings such as "truths of things," "effects of names and attributes," "knowledge of Haqq," and "images of beings for divine knowledge." 34 Pursuant to such definitions, immutable entities are a store of divine knowledge that includes the content of the attribute of knowledge for divine essence and the truth and presence of contingent beings in divine knowledge in terms of the universe; in other words, it is a store in which things subject to knowledge of Allah and the reality of particular beings in universe take place. ${ }^{35}$ In this respect, the truth is distinguished by its feature of "being around" because of the ontological relationship between Allah and the universe. Moreover, He is passive in terms of the attribute of knowledge ascribed to Him and is active in proportion to the contingent beings that He determines. Things in the domain of phenomenal being were already potentially present in divine self before becoming reasonable and sensible objects. The category of created beings is the truths that have been actualized in line with their truths in divine knowledge.

As a constitutive and decisive concept in the relationship between Allah and the universe, immutable entities are the sole concept that enables determining the position and actuality of contingent beings with respect to Allah. Accordingly, immutable entities are the fundamental concept that causes us to render a judgment about the essence and content of the unity of existence. The definition "existence

33 Al-Qūnawī, Tasavvuf Metafiziği, 23.

34 For the concept, see Ibn 'Arabī, Fuṣūṣ al-ḥikam (ed. Abū l-'Alā 'Afîfī; Beirut: Dār al-Kitāb al-'Arabī, 1980), 60, 81, 99, 111; al-jîlī, al-Insān al-kāmil fì ma'rifat alawākhir wa-l-awā’il (Cairo: al-Mațba'a al-Azhariyya, 1963), 15, 51.

35 For an assessment of invariable truths, see Abū 1-'Alā 'Afîfī, Nazariyyāt alIslämiyyìn fì l-kalima (The Logos) (Cairo: Maṭba'at al-Ma'had al-Tlmī al-Faransī li1-Āthār al-Sharqiyya, 1934); Izutsu, Sufism and Taoism: A Comparative Study of Key Philosophical Concepts (Berkeley \& Los Angeles, CA: University of California Press, 1984), 159-196. 
is an addition to truth in those other than Haqq" in the beginning of this chapter can now be re-established as "existence is an addition to truths in contingent beings."

Ibn 'Arabī and his followers advanced two fundamental propositions about immutable entities to ensure a more direct understanding of the unity of existence:

\section{The first is that truths are uncreated things.}

Al-Qūnawi treats the question of contingent essences in his correspondences with Nașīr al-Dīn al-Ṭūsī, and asks whether contingent essences are created. ${ }^{36}$ Al-Qūnawi not only analyzes the knowledge and final verdict of mind about contingent essences but also assesses various possibilities. The mind can attempt to prove that essences are either created or not created. However, both cases may result in problems. If essences are not created, they should not have existence. If we assert the contrary, essences would have to be the same as the Necessary Being due to the necessity of their existence and spontaneity, whereupon they could not be contingent. Contingency means that something possesses the characteristics of possibility and requirement, which necessitates that it obtains its existence from some other thing. If something did not feature contingency due to its existence, then it should have been necessary. Conversely, if contingent essences have a type of existence even prior to creation, they will escape their essential characteristics (possibility and requirement). Sufis and the scholars on truth agree about the rule that truths are subject to no variation or alteration. Therefore, judgment about contingent essences should not result in a verdict that is different from their added features and that derive themselves from such a feature.

If we are to assume that contingent essences exist in any manner even though they are uncreated, then it is necessary to distinguish the relationship of the existence obtained from God between that of existence possessed of contingent beings. If both existences are the same, this leads to a tautology, which al-Qūnawi often mentions and calls impossible; consequently, God provides no meaning for existence. If we accept that they are two separate existences, this would also be impossible, because it has already been admitted that there is a common and single existence among all contingent beings. Another consequence follows if we accept that contingent essences are not

\footnotetext{
36 Al-Qūnawī, Yazışmalar, 59.
} 
created: we accept that all contingent essences revert from the status of necessity to contingency and from eternal and private abstemiousness to the rank of being created. In that case, we must admit that in the course of acquiring existence, contingent beings proceed from perfection towards insufficiency. Thus far, we have seen the possibilities and contradiction to emerge once we assert contingent essences as uncreated.

Can we protect the mind from encountering contradiction by accepting that contingent essences are created? If so, Haqq should be the origin of infinite absences and the reason for differentiation among them. Accordingly, the consequence of the effect of Haqq would be a nonexistent situation in a nonexistent thing, because those that do not exist cannot differ from one another in the state of nothingness. ${ }^{37}$

With respect to the matter of the relationship between essence and existence in God, the objective of al-Qunnawi is to prove the impossibility of attaining definitive judgments about contingent essences merely through the mind. According to him, the answers to be provided by the human mind about contingent essences can always be disproved in various aspects. The precise information in this respect can be information acquired through pleasure and pursuant to that information, "essences are uncreated and have a kind of existence."38

What does it mean when we say that immutable entities are uncreated as essence and truth of contingent beings? What is the connection between such fact and the unity of existence? The response by al-Qūnawi includes the following assessment. As noted above, the truths of contingent beings cannot be qualified as being created. Indeed, "to be created" means to be present, otherwise something that has no existence cannot be created. If we admit that truths are created, then eternal knowledge should have had an effect on the appearance of the known in eternity. However, the truths known by knowledge are not outside the one who knows them. In other words,

37 For details about the analyses by al-Qūnawi on the problems that will unfold through the judgment of the mind regarding whether invariable truths, as contingent essences, are created, see Yazışalar, 59-63.

Al-Qūnawi says "The true observation and authentic pleasure signify that the essences are uncreated and that they have a kind of existence; this very existence is the one which belongs to essences in the way they become apparent in eternal and everlasting knowledge of Haqq." See Yazışmalar, 61. 
we can discuss a kind of existence of the truths within the self of one who knows them, because they are nonexistent in themselves. If to be created means to exist, the truths should have been equal to the Haqq who knows them in terms of being or Haqq should have been a space for acceptance of the effect from Himself to Himself, and a quality for others to be able to consider truths as created. ${ }^{39}$ According to al-Qūnawī, all such claims are void. For us, the consequence of alQunawì's efforts to prove that the truths of the contingent are uncreated is relevant to the content of the unity of existence. Accordingly, to claim that the truths of contingent beings are created would point to their existence independent from Haqq, which would constitute a contradiction with absolute unity. "The to-be-created of truths of the contingent impairs the absoluteness of the unity of Haqq," says alQūnawīi. ${ }^{40}$

Therefore, the main principle is that existence and essence are separate, and the contingent being obtains its existence from Necessary Being. The first result of this principle is that essences are uncreated. That essences are uncreated is the most fundamental issue regarding the conception of the unity of existence. If essences are uncreated, the tension between an existence and an existing plurality dies out; namely, it becomes possible to explain plurality in the universe of beings through the doctrine of the unity of existence based on absolute unity. That truths are uncreated means that they have no reality independent of a knowledge of Allah and that absolute unity is preserved in the system of the unity of existence. Therefore, one of the fundamental propositions and inclusions of the unity of existence is that in divine knowledge, the immutable entities of contingent beings are uncreated.

Second, existence is attached to immutable entities, which is the truth of contingent beings.

Ibn 'Arabi formulates the problem as follows: "One who is invariable in nothingness has not even smelled existence. They remain in their original condition even though their images in beings reproduce. The truth in all of them is one. The plurality is in the names." ${ }^{11}$

Al-Qūnawī, Tasavvuf Metafiziği, 23-24.

Al-Qūnawī, ibid., 24.

41 Ibn 'Arabī, Fuṣūṣ al-ḅikam, 76. 
What does this mean? To understand, we should know that Ibn 'Arabì and his commentators discuss two modes of existence, namely, thubūtì and wujūdi existence. In the terminology of Ibn 'Arabī, thubüt means the existence of contingent essence in the knowledge of Allah; therefore, it principally signifies nothingness. Therefore, despite being invariable within the knowledge (wisdom) of Allah, immutable entities are actually nonexistent because they have no independent and autonomous state of existence. ${ }^{42}$ In other words, to be absent means to be nonpresent. Wujū $d \bar{\imath}$ existence means to have an existence in outside world; Sufis call this the presence of truths. Therefore, particular beings are immutable entities disguised in existence. The assertion by Ibn 'Arabī that truths cannot even smell existence can be evaluated in this respect. Accordingly, it is necessary to distinguish between the thubüti presence of contingent essences in the knowledge of Allah and their existence outside. At this point, we can indicate that immutable entities are uncreated because they do not exist in terms of being present within the knowledge of Allah; moreover, pursuant to the definition of contingency, they have obtained their existence from another being. Thereupon existence opts for truth afterwards. Ibn 'Arabī expresses the status of contingent being before necessary being as follows:

That which exists afterwards precisely needs one to make it exist due to the subsequence and self-possibility of the former. Therefore, the being of the thing which exists afterwards originates from another. There is a relation of indigence between the subsequent existence and that who makes it exist. The being, which the subsequent existence is grounded on, should essentially be the Necessary Being. ${ }^{43}$

Ibn 'Arabī clearly indicates that the contingent being, namely, the truths, obtain their existence from Haqq. Thus, existence is added to contingent truths from outside. Ibn 'Arabī often defines contingency as a "state of want." Contingency includes the meaning of the "state of needing another for existence." ${ }^{\prime 4}$ This is a crucial point, because Ibn 'Arabī, claiming that the essences of contingent beings are uncreated, equally asserts that it is Allah who provides them with existence and

42 For thubūtì and wujūidì existence, see al-Qūnawī, al-Nafahāt al-ilābiyya (along with al-Sirr al-rabbānì al-ma'rǘf bi-l-Nușūss, ed. Ahmad Farīd al-Mazìdī; Beirut: Dār al-Kutub al-'Tlmiyya, 2007), 26-30.

43 Ibn 'Arabī, Fuṣūṣ al-ḥikam, 53.

44 Ibn 'Arabī, ibid., 54. 
that the creation thus actualizes. However, it is worth noting that for Ibn 'Arabī, creation is not from nothing, instead it instills existence to truths that are invariable within divine knowledge or wisdom.

What is the relationship between this problem and the unity of existence? The following statements by al-Qūnawi may help us understand the meaning of the provision of existence to contingent essences by Haqq in terms of the unity of existence:

Since One can not manifest any other than One, only 'One' emerges from Haqq regarding unity of existence. For us, that One is 'the general being who inspires truths' on existent or nonexistent things whose existence eternal knowledge decides.' Contrary to views of theoretical philosophers, general being is common among al-qalam al-a $q \bar{a}$, the first existent called al-'aql al-awwal, and other beings ... Thus, it is certain that the known things are not uncreated in the mentioned manner and that there are not two separate existences in question. On the contrary, the being is one, this being is common among others and is obtained from Haqq. ${ }^{45}$

At this stage, al-Qūnawī notes a notable problem. All categories of being have taken their being from general existence; in this respect, all those who exist are common in terms of existing. Therefore, we refer to a single existence with respect to all categories of being. What emerges from Absolute Being is merely the manifestation of being, and the being is equal among all contingents. This fact reminds us again of the following definition by al-Kāshānī: "Unity of existence means indivisibility of existence as necessary and contingent." Accordingly, the common element in all categories of being is general existence with respect to the relationship between Allah and the universe. Then, again, what is the source of difference among the contingent? If existence is equal for all the contingent beings, it cannot be the origin of differences. Sufis, who defend the unity of existence, principally refer to immutable entities as the primary fact in order to explain differences in the universe and among those who exist. The differences among the contingent originate from their uncreated dispositions. What leads to differences and reproduces existences are the uncreated dispositions and essences. Al-Qūnawī explains this by saying that "the state of contingency reproduces the Only Existent emerging from Haqq as the absolute and peculiar being by means of

45 Al-Qūnawī, Tasavvuf Metafiziğ i, 23-24. 
its restrictions and various dispositions." the contingent beings is the contingent beings themselves and their uncreated essence. Ibn 'Arabí indicates "the plurality is in nomination. The names are connections, which are, in turn, the "nonexistent things." "47 Therefore, the origin of difference among contingent essences is not their existence but their uncreated dispositions.

As for the relationship between essence and existence in contingent beings, essences are not created, and Haqq provides them with existence. What does this mean with respect to the relationship between Allah and the universe? To say that contingent essences are uncreated will render impossible that they have an autonomous existence independent from knowledge of Allah; moreover, it enables us to explain and reduce both plurality and difference. Indeed, the plurality in the universe is absent in divine knowledge, and this fact does not prejudice divine unity. However, contingent essences have been able to become existent by obtaining their existence from Haqq. Because all categories of being, including the contingent, obtain existence from general existent and because the general existent is common in all existents, we talk about not two, but only one domain of existence, which enables the preservation of the unity of existence with respect to the relationship between Allah and the universe. Thereupon, in terms of unity-plurality and Allah-universe relations, the unity of existence is based not only on the unity and singularity of existence in all categories but also on the variety and plurality of dispositions in divine knowledge.

\section{Conclusion}

The unity of existence is a Sufi term that explains the relationship between Allah-universe and man via observation and that expresses the doctrine by Ibn 'Arabī. The first user of the term is a notable question, as is the analysis of its meaning, content, inclusions, and grounds, and require significant research. Ibn 'Arabì has been the subject of several accusations due to the difficulty and complexity of a determination on the content of the concept. In this regard, it is crucial to determine the content and inclusion of the concept of unity

\footnotetext{
46 Al-Qūnawī, Fusûsü'l-Hikem'in Sirlart: al-Fukūk fì asrār mustanidāt ḅikam alFuṣūṣ (translated into Turkish by Ekrem Demirli; Istanbul: İz Yayınc1lık, 2002), 147.

47 Ibn 'Arabī, Fuṣūṣ al-ḥikam, 76.
} 
of existence. What is the unity of existence? In this article, we attempted to assert that the fundamental principle underlying the unity of existence should be sought in the relationship between essence and existence, a point of debate in Islamic philosophy and theology and that the relationship between essence and existence entails the unity of existence.

Sufis, who defend the unity of existence, formulate the relationship between essence and existence as follows: "The existence for Haqq is identical with His self. For all others, it is an addition to the truth." With respect to Haqq, Sufis consider existence as identical with self, and an addition to it. Accordingly, they see the concept of existence as the primary element and in this way, they attain the fundamental proposition of the unity of existence, namely, "existence as such is Haqq." This proposition includes both the absolute unity (singularity) and simplicity of existence and advances that existence consists of Haqq. With respect to the term "contingent" in the definition "existence is an addition onto the truth of the contingent," Sufis identify this concept with immutable entities in Sufi terminology. For Sufis, the immutable entities, which are the truth of contingent beings, comprise the intermediate category that makes up the Allah-universe or unity-plurality relationships. Thus, this is the exclusive concept that explains how plurality emerges from unity. Next, two principles related to the abovementioned concept can be determined. First, the truths are uncreated; second, because truths do not even have a smell of existence, the latter is later added to truth. Through the first principle, Sufis ensured that the truth of contingent beings is certain in divine knowledge and that such truths was neither autonomous nor independent because they lacked an outside existence. Moreover, Sufis preserved the principle of absolute unity by relating the plurality to the names and dispositions of truths. Conversely, the assertion that existence is added to truths afterwards enables the preservation of creation in the sense of providing truths with existence. In addition, because truths obtain existence from that of Haqq, namely, the general existent, it is possible to defend the idea of single existence without dividing it in two categories such as necessary and contingent. This single existence is common in both Haqq and contingent beings. Therefore, the second proposition about the unity of existence is relevant to immutable entities. Truths are uncreated and existence is added to them afterwards. Accordingly, the unity of existence is also based on the relationship between essence and existence in Allah 
and contingent beings. In short, the unity of existence consists of the following proposition: "existence as such is Haqq; immutable entities are uncreated and existence is added to them afterwards."

\section{REFERENCES}

'Afîfî, Abū l-'Alā, Nazariyyāt al-Islāmiyyìn fì l-kalima (The Logos) (Cairo: Mațba'at al-Ma'had al-'Tlmī al-Faransī li-l-Āthār al-Sharqiyya, 1934).

Atay, Hüseyin, İbn Sina'da Varlkk Nazariyesi (Ankara: Gelişim Matbaası, 1983).

"Mâhiyet-Varlık Ayırımı," in Müjgan Cunbur and Orhan Doğan (eds.), Uluslararası İbn Sina Sempozyumu (Bildiriler) (Ankara: Başbakanlık Basımevi, 1984), 139-166.

al-Būsnawī, 'Abd Allāh 'Abdī ibn Muhammad 'Abd Allāh, Kitāb al-qirār alrūḥ̄ al-mamdūd li-l-adyāf al-wāridīn min marātib al-wujūd (MS Istanbul: Süleymaniye Library, Cârullah Efendi, no. 2129), fols. 1a-27b.

Corbin, Henry, History of Islamic Philosophy (translated into English by Liadain Sherrard and Philip Sherrard; London \& New York: Kegan Paul International \& The Institute of Ismaili Studies, 1993).

al-Ḥakīm, Sucād, al-Mu'jam al-șüfì: al-Hikma fì ḥudūd al-kalima (Beirut: Dandara li-l-Ṭibā'a wa-l-Nashr, 1981).

Ibn 'Arabī, Abū 'Abd Allāh Muhyī al-Dīn Muhammad ibn 'Alī, Fuṣūṣ alb̧ikam (ed. Abū l-'Alā 'Afîfí; Beirut: Dār al-Kitāb al-'Arabī, 1980).

al-Futūhāt al-Makkiyya, 14 vols., (ed. 'Uthmān Yahyā; $2^{\text {nd }}$ edn., Cairo: al-Hay’a al-Miṣriyya al-'Āmma li-l-Kitāb, 1985).

Ibn Sīnā, Abū 'Alī Ḥusayn ibn 'Abd Allāh ibn 'Alī, İsaretler ve Tembibler [= al-Ishārāt wa-l-tanbīhät (translated into Turkish, with the original text, by Ali Durusoy, Muhittin Macit, and Ekrem Demirli; Istanbul: Litera Yayıncilik, 2005).

Kitâbu'ş-Şifâ: Metafizik [= Kitāb al-Shifā': al-Ilāhiyyāt], 2 vols, (translated into Turkish, with the original text, by Ekrem Demirli and Ömer Türker; Istanbul: Litera Yayıncilık, 2005).

al-Imām al-Rabbānī, Abū 1-Barakāt Aḥmad ibn 'Abd al-Aḥad ibn Zayn al'ābidīn al-Sirhindī, Mektûbât [al-Maktūbāt], 2 vols., (translated into Turkish by Abdulkadir Akçiçek; Istanbul: Fatih Kitabevi, n.d.). 
Izutsu, Toshihiko, Sufism and Taoism: A Comparative Study of Key Philosophical Concepts (Berkeley \& Los Angeles, CA: University of California Press, 1984).

The Concept and Reality of Existence (Kuala Lumpur: Islamic Book Trust, 2007).

Jāmī, Abū l-Barakāt Nūr al-Dīn 'Abd al-Raḥmān ibn Aḥmad ibn Muḥammad, al-Durra al-fäkbira fì taḥqīa madhāhib al-șüfiyya wa-lmutakalliminn wa-l-hukamā al-mutaqaddiminn (eds. Nicolas Heer and 'Alī Mūsawī Bahbahānī; Tehran: McGill University Institute of Islamic Studies \& Dānishgāh-i Tehran, 1980).

Nefahâtü'l-üns [= Nafaḥāt al-uns min ḥadarāt al-quds] (eds. Süleyman Uludağ and Mustafa Kara; Istanbul: Marifet Yayınları, 1995).

al-Jìlī, Quṭb al-Dīn 'Abd al-Karīm ibn Ibrāhīm ibn 'Abd al-Karīm, al-Insān alkāmil fì ma'rifat al-awākhir wa-l-awā'il (Cairo: al-Mațba'a alAzhariyya, 1963).

al-Kamālāt al-ilāhiyya fì l-șifāt al-Muḅammadiyya (ed. Sa'īd 'Abd al-Fattāh; Cairo: Maktabat 'Ālam al-Fikr, 1997).

Marātib al-wujūd wa-ḅaqīqat kull mawjūd (Cairo: Maktabat alQāhira, 1999).

Kaya, Mahmut, "Mâhiyet ve Varlık Konusunda İbn Rüşd'ün İbn Sînâ'y1 Eleştirmesi," in Aydın Sayılı (ed.), İbn Sînâ: Doğumunun Bininci Yılı Armağanı (Ankara: Türk Tarih Kurumu Basımevi, 1984), 453-459.

al-Nābulusī, 'Abd al-Ghanī ibn Ismā̄îl, Gerçek Varlık: Vahdet-i Vücûd'un Müdafaası [al-Wujūd al-ḩaqq wa-l-khițāb al-șidq] (translated into Turkish by Ekrem Demirli; Istanbul: İz Yayıncilık, 2003).

al-Kāshānī (as al-Qāshānī), Kamāl al-Dīn 'Abd al-Razzāq ibn Aḥmad, Laṭā'if al-a lām fì ishārāt abl al-ilhām (eds. Aḥmad 'Abd al-Rahīm al-Sāyị̣, Tawfīq 'Alī Wahba, and 'Āmir al-Najjār; Cairo: Maktabat al-Thaqāfa alDīniyya, 2005).

al-Qayṣarī, Sharaf al-Dīn Dāwūd ibn Maḥmūd ibn Muhammad, Sharḥ Fuṣūṣ al-ḥikam (ed. Jalāl al-Dīn Āshtiyānī; Tehran: Sharikat-i Intishārāt-i 'Tlmī va-Farhangī, 1383 HS).

al-Qūnawī, Ṣadr al-Dīn Muḥammad ibn Isḥāq ibn Muḥammad, al-Nafaḥāt al-ilābiyya (along with al-Sirr al-rabbānī al-ma'rūf bi-l-Nușūṣ, ed. Aḥmad Farīd al-Mazīdī; Beirut: Dār al-Kutub al-clmiyya, 2007). 
Fusûsü'l-Hikem'in Sirları: al-Fukūk fì asrār mustanidāt ḅikam alFușūṣ (translated into Turkish by Ekrem Demirli; Istanbul: İz Yayınc1lık, 2002).

Sadreddin Konevî ile Nasireddin Tûsî Arasında Yazısmalar: alMurāsalāt (translated into Turkish by Ekrem Demirli; Istanbul: İz Yayınc1lı, 2002).

Tasavvuf Metafiziği: Miftāh ghayb al-jam wa-l-wujūd (translated into Turkish by Ekrem Demirli; Istanbul: İz Yayıncilık, 2002).

al-Qushayrī, Abū 1-Qāsim Zayn al-Islām 'Abd al-Karīm ibn Hawāzin, alRisāla al-Qushayriyya (eds. Ma'rūf Mușțafā Zurayq and 'Alī 'Abd alḤamīd Balțajī; Beirut: Dār al-Khayr, 1991).

al-Rāzī, Abū 'Abd Allāh Fakhr al-Dīn Muḥammad ibn 'Umar, al-Mațālib al'āliya min al-cilm al-ilāhī, 9 vols. in 5 vols., (ed. Aḥmad Hijāzī alSaqqā; Beirut: Dār al-Kitāb al-'Arabī, 1987). 